\author{
Dr. sc. Zoran Šinković, docent \\ Pravni fakultet Sveučilište u Splitu
}

\title{
NAČELO GOSPODARSKOG PRISTUPA ČINJENICAMA BITNIMA ZA OPOREZIVANJE
}

\author{
UDK: 336.2 \\ Primljeno: 15. 12. 2017. \\ Pregledni rad
}

\begin{abstract}
Načela su korisna u utvrđivanju značenja pravila, to jest u tumačenju poreznog prava, a kombinacija načela, poput općeg pravila, i specifičnih pravila pomaže stvaranju integriranog porezno-pravnog sustava. U tumačenju poreznih propisa gospodarsko tumačenje ima značaju ulogu odnosno načelo gospodarskog pristupa činjenicama bitnima za oporezivanje, koje kodificira načelo prevage sadržaja u odnosu na formu. Na istom je tragu moguće istaknuti prividne i prikrivene pravne poslove bez kojih bi primjena navedenog načela u praksi bila znatno otežana. Nužno je promijeniti odredbe Općeg poreznog zakona vezane za načelo gospodarskog pristupa činjenicama bitnima za oporezivanje i prividne pravne poslove, što bi zasigurno pomoglo da porezna odnosno sudska praksa postanu još kvalitetnije u primjeni poreznih propisa.
\end{abstract}

Ključne riječi: gospodarski pristup, prividni pravni poslovi, prikriveni pravni poslovi

\section{UVOD}

Gospodarsko tumačenje pravnih propisa predstavlja specifičnost poreznog prava. Doduše, i u drugim pravnim disciplinama poznato je takvo tumačenje, ali se ono rijetko priznaje.

Nije porezno pravo bez razloga onaj segment prava iz kojeg se razvilo gospodarsko tumačenje pravnih propisa. Porezno je pravo, naime, u najužoj vezi s takvim događajima i činjenicama koje se isplati oporezivati. Takva uska povezanost poreznog prava s navedenim događajima i činjenicama posljedica je toga što država najveći dio svojih prihoda ostvaruje ubiranjem poreza. Ali, ubirući poreze, država mora voditi računa i o načelu gospodarske sposobnosti, tj. mora naplaćivati poreze u skladu s gospodarskom snagom poreznih obveznika. A pitanje određivanja gospodarske sposobnosti nemoguće je bez zauzimanja gospodarskog stajališta i gospodarskog tumačenja pravnih pojmova. ${ }^{1}$

Iz toga proizlazi da gospodarsko tumačenje poreznih propisa i nije ništa drugo nego tumačenje identično teleološkom postupku tumačenja. I kod gospodarskog 540.

Bo. Jelčić i drugi, Financijsko pravo i financijska znanost, Narodne novine, Zagreb, 2008., str. 
tumačenja se, kao i kod teleološkog, polazi od cilja koji porezni propis mora ostvariti, a to je pravedno oporezivanje. ${ }^{2}$

Unatoč tome što se gospodarsko tumačenje u poreznom pravu primjenjuje već od dvadesetih godina prošlog stoljeća, do današnjih dana nema njegove precizne definicije. ${ }^{3}$

Za naše potrebe, gospodarsko tumačenje poreznih propisa opisat ćemo kao pripisivanje gospodarskog smisla pojmovima iz drugih pravnih područja, posebno iz područja građanskog prava. ${ }^{4}$

Navest ćemo slučajeve kod kojih se najčešće pojavljuje potreba za primjenom metode gospodarskog tumačenja pravnih pojmova: a) kod nezakonitih postupaka i postupaka protivnih javnom moralu, b) kod prividnih pravnih poslova, c) kod priračunavanja gospodarskih dobara, d) kod odnosa povjerenja, odnosno skrivenog zastupništva, e) kod posjedovanja tuđeg predmeta i f) kod vlasništva u funkciji osiguranja.

\section{TUMAČENJE ODNOSNO UTVRĐIVANJE ČINJENICA PREMA GOSPODARSKOJ BITI}

U hrvatskom poreznom pravu načelo gospodarskog pristupa činjenicama bitnima za oporezivanje regulirano je čl. 11. Općeg poreznog zakona. ${ }^{5}$

Čl. 11. st. 1. Općeg poreznog zakona propisuje da se porezne činjenice utvrđuju prema njihovoj gospodarskoj biti. ${ }^{6}$

Iz navedene zakonske odredbe zaključuje se da za utvrđivanje porezne obveze određenog subjekta nije bitan njegov pravni položaj u odnosu na djelatnost iz koje nastaje porezna obveza nego gospodarski učinci, što ih je, bilo baveći se određenom djelatnošću, bilo temeljem drugih osnova, postigao. ${ }^{7}$

Čl. 11. st. 2. Općeg poreznog zakona propisuje ako je prihod, dohodak, dobit ili druga procjenjiva korist ostvarena bez pravne osnove, porezno tijelo utvrdit će poreznu obvezu u skladu s posebnim zakonom kojim se uređuje pojedina vrsta poreza.

2 Ibid.

3 Ibid.

4 O odnosu između financijskog (poreznog) prava i građanskog prava podrobnije vidjeti u: D. Birk i drugi, Steuerrecht, 18. Auflage, C. F. Müller, Heidelberg, 2015./16., str. 17-18, K. D. Drüen, Allgemeines Steuerrecht, 16. Auflage, Alpmann Schmidt, Münster, 2017., str. 2-4.

5 Narodne novine, br. 115/16.

6 Gospodarska cjelina je sva imovina i obveze što u poslovnom i organizacijskom smislu čini samostalni subjekt, odnosno subjekt sposoban za samostalno poslovanje (čl. 38. st. 1. Općeg poreznog zakona). Vrijednost gospodarske cjeline procjenjuje se prema tržišnoj cijeni, a tržišnom se cijenom smatra ona cijena koja bi se mogla postići u uobičajenom poslovnom prometu. Neuobičajeni popusti u poslovanju ili osobni popusti ne uzimaju se u obzir (čl. 41. st. 1. i 2. Općeg poreznog zakona).

M. Budić i drugi, Opći porezni zakon s komentarom, Institut za javne financije, Zagreb, 2001., str. 
Iz navedene zakonske odredbe zaključuje se da na utvrđivanje porezne obveze ne utječe činjenica je li prihod, dohodak, dobit ili druga procjenjiva korist stečena na odgovarajućoj pravnoj osnovi (vlasništvo, legitimni posjed) ili bez pravne osnove (uzurpacija). Onaj tko je ostvario prihod, dohodak, dobit ili drugu procjenjivu korist dužan je platiti porez bez obzira na način stjecanja, dakle oporezuje se i protupravno stjecanje, samo što se porezna obveza utvrđuje sukladno zakonu što uređuje pojedinu vrstu poreza. Svi ostali odnosi i njihovo pravno sređivanje nisu predmet poreznog postupka, a zainteresirani ih mogu pokretati pred drugim nadležnim tijelima državne vlasti (upravnim tijelima, sudovima). ${ }^{8}$

Čl. 11. st. 3. Općeg poreznog zakona propisuje ako je u kaznenom ili prekršajnom postupku pravomoćnom odlukom izrečena zaštitna mjera oduzimanja imovinske koristi ostvarene protupravnom radnjom, porezni akt kojim je utvrđena porezna obveza poništit će se na zahtjev poreznog obveznika.

Iz navedene zakonske odredbe zaključuje se da će se porezni akt (porezno rješenje) kojim se utvrđuje porezna obveza poništiti na zahtjev poreznog obveznika, ako su mu pravomoćnom odlukom u kaznenom ili prekršajnom postupku utvrđene vrsta i visina kazne odnosno izrečena zaštitna mjera oduzimanja imovinske koristi iz razloga što je u tom slučaju stjecanje (neke imovinske koristi) poništeno, a kako nema porezne osnovice, nema ni porezne obveze. Ako bi, na primjer, kazneni ili prekršajni postupak bili pravomoćno okončani prije poreznog postupka i imovinska korist oduzeta, postupak oporezivanja ne bi se provodio.

Drugim riječima, $u$ hrvatskom poreznom zakonodavstvu ne nalazimo opće pravilo protiv izbjegavanja poreza. ${ }^{9}{ }^{10}$ Međutim, postoje određene odredbe kojima

8 Ibid.

9 Podrobnije vidjeti u: T. Rogić Lugarić i drugi, „Pravni status poreznih izdataka: Stanje i perspektive“, Zbornik radova "Skrivena javna potrošnja: "sadašnjost i budućnost poreznih izdataka“, Institut za javne financije, Zagreb, 2012., str. 175-196.

10 Zakonodavni instrumenti namijenjeni suprotstavljanju zakonitom izbjegavanju poreza dijele se u dvije skupine: 1) tzv. posebna pravila, i 2) tzv. opća pravila. Porezni sustavi većeg broja država sadrže obje vrste instrumenata. Glavna je razlika u njihovom opsegu primjene, tj. u vrsti ponašanja protiv kojega su usmjereni. Posebna su pravila namijenjena sprečavanju specifičnih struktura zakonitog izbjegavanja poreza, poput transfernih cijena ili potkapitalizacije. S druge strane, opća pravila imaju puno širi opseg primjena te čine svojevrsnu ,zaštitnu mrežu“ protiv izbjegavanja poreza. Temeljna je uloga općeg pravila označiti zakonsku granicu između prihvatljivog poreznog planiranja i neprihvatljivog izbjegavanja poreza, $i$ to tako da se poreznim tijelima i sudovima na raspolaganje stavi niz kriterija koje moraju uzeti u obzir prilikom odlučivanja o prihvatljivosti specifičnog ponašanja poreznog obveznika. Iako se opća pravila razlikuju od države do države, moguće je odrediti i neka njihova zajednička obilježja. Prvo, opće se pravilo može primijeniti samo ako porezni obveznik poduzimanjem određene transakcije (ili više njih), ostvaruje poreznu pogodnost (npr. porezno izuzeće), koju inače ne bi ostvario. Drugo, primjena općeg pravila ovisi o svrsi ili cilju koji stoji iza transakcije. Opće se pravilo primjenjuje samo ako je svrha transakcije bila ostvarenje porezne pogodnosti, što navodi na zaključak da je svrha ključni element koncepta zakonitog izbjegavanja poreza. Iako se utvrđivanje svrhe, inherentno mentalnog elementa transakcije, može činiti složenim, iskustva većeg broja država ukazuju na moguće oslanjanje na određene objektivne elemente (npr. komercijalna supstanca transakcije). U tom smislu očiti se problem sastoji u razlikovanju „porezne svrhe“" transakcije od druge poslovne (komercijalne) svrhe. Naime, iz perspektive poreznih obveznika, porezne pogodnosti pridonose povećanju ukupnog neto povrata, što promatranoj transakciji daje poslovno opravdanje. Sa stajališta nositelja porezne politike, kako je već navedeno supra (gore), od ključne je važnosti označiti granicu između poreznog planiranja i izbjegavanja poreza, a kriterij svrhe transakcije čini se nepodobnim za ostvarenje tog cilja. To se potvrđuje i u vidu tzv. poreznih izdataka, putem kojih 
Dr. sc. Zoran Šinković: Načelo gospodarskog pristupa činjenicama bitnima za oporezivanje Zbornik radova Pravnog fakulteta u Splitu, god. 55, 1/2018., str. 201.- 219.

je moguće ostvariti slične ciljeve. A od posebnog je značaja, kako je već gore objašnjeno, odredba iz čl. 11. st. 1. Općeg poreznog zakona, koja propisuje tzv. „gospodarski pristup“ u postupku utvrđivanja porezne obveze, odnosno kojom se kodificira načelo prevage sadržaja u odnosu na formu. ${ }^{11}$ Načelo gospodarskog pristupa omogućuje poreznim tijelima da oporezuju dobit ostvarenu kaznenim djelom, s obzirom na to da se porez nameće na ekonomsku supstancu, a priroda pravnog posla koji je doveo do ostvarenja dobiti nije bitna za porezno pravo. Sukladno tomu, načelo gospodarskog pristupa može se smatrati i potencijalno moćnim alatom usmjerenim protiv izbjegavanja poreza, usporedivim s općim pravilom. Međutim, odredbe Općeg poreznog zakona o gospodarskom pristupu nedovoljno su precizne i ne pružaju detaljnije upute za njihovu primjenu poreznim tijelima. Stoga nije iznenađujuće da - unatoč tomu što su ove odredbe u nepromijenjenom obliku na snazi još od 2001. godine - njihova uloga pri sprečavanju izbjegavanja poreza nije prepoznata od strane poreznih tijela. ${ }^{12} 13$

država potiče poduzimanje određenih aktivnosti i kroz koje se ostvaruje regulatorna funkcija oporezivanja. Zato je ključni korak u kvalifikaciji određene porezno motivirane aktivnosti kao izbjegavanja poreza utvrđivanje nesuglasja između njezinih rezultata, tj. ostvarene porezne pogodnosti, i cilja relevantnog poreznog pravila. Drugim riječima, konstitutivni element izbjegavanja poreza jest zlouporaba (poreznog) prava, što potvrđuju i opća pravila u mnogim državama. Dodatna teškoća u oslanjanju na svrhu transakcije kao uvjet za primjenu općeg pravila krije se u relativnoj važnosti drugih mogućih ciljeva transakcije. Iako ne postoji jedinstveno rješenje, postojanje značajne neporezne svrhe transakcije obično isključuje primjenu općeg pravila. Ako su svi gore navedeni uvjeti za primjenu općeg pravila u odnosu na konkretnu transakciju ispunjeni, porezna tijela ovlaštena su uskratiti ili poništiti ostvarene porezne pogodnosti. Također, u brojnim državama porezna tijela imaju i pravo rekonstrukcije pravnog posla u skladu s utvrđenom ekonomskom stvarnošću te posljedičnog nametanja poreza na novoutvrđeni pravni posao. Iako prepuštanje tako širokih ovlasti poreznoj administraciji izaziva prijepore, to je ključan element svakog općeg pravila. U svakom slučaju, nositelji porezne politike moraju težiti da pomoću drugih obilježja općeg pravila daju poreznim tijelima dovoljno precizne smjernice za njegovu pravilnu primjenu. Jedno od porezno-tehničkih rješenja sastoji se i u ustanovljavanju posebnog savjetodavnog tijela, tzv. odbora za primjenu općeg pravila, čiji je zadatak štititi interese poreznog obveznika i davati savjete poreznim tijelima. Navedeno prema: S. Gadžo i drugi, „Analiza normativnog okvira za sprječavanje zakonitog izbjegavanja poreza u Hrvatskoj: Prijedlog izmjena u skladu s pravom Europske unije“, Financijska teorija i praksa, br. 25., Institut za javne financije, Zagreb, 2014., str. 281-282, C. Atkinson, „General antiavoidance rules: Exploring the balance between the taxpayer`s need for certainty and the government's need to prevent tax avoidance“, Journal of Australian Taxation, No. 14/12., str. 1-56.

11 Glavom 1 (7) mađarskog Zakona o poreznoj upravi doktrina da je sadržaj važniji od forme dopušta poreznim vlastima djelovanje na temelju norme kojom je propisano da je, za potrebe oporezivanja, pravna bit važnija od pravne forme, ali im ne dopušta da pri oporezivanju uzimaju u obzir samo ekonomsku bit, a zanemaruju pravnu. Navedeno prema: R. Prebble, „Treba li Hrvatska opće pravilo za sprječavanje zakonitog izbjegavanja porezne obveze?“, Prijedlog promjena važećega hrvatskog zakonodavstva, Financijska teorija i praksa, br. 29., Institut za javne financije, Zagreb, 2005., str. 275.

12 T. Rogić Lugarić i drugi, Pravni status... o. c., str. 175-196.

13 U tom kontekstu valja navesti i čl. 39. Općeg poreznog zakona u kojem se propisuje ako neka druga osoba, a ne vlasnik, ima pravo raspolaganja gospodarskom cjelinom na način da može vlasnika gospodarski isključiti od utjecaja na to dobro, tada se u poreznom smislu smatra da ta gospodarska cjelina pripada toj drugoj osobi. Kod fiducijarnih (povjereničkih) odnosa smatra se da gospodarska cjelina pripada fiducijaru (povjereniku). 


\section{KRATKI PRIKAZ PRIMJENE NAČELA GOSPODARSKOG PRISTUPA ČINJENICAMA BITNIMA ZA OPOREZIVANJE U KOMPARATIVNIM POREZNIM SUSTAVIMA}

U vajmarskoj i nacističkoj Njemačkoj, Zakon o javnim davanjima Rajha - Reicha (njem. Reichsabgabenordnung) iz 1919. godine propisao je da se porezni zakoni tumače u skladu s ,gospodarskom interpretacijom“, što su sudovi u praksi često primjenjivali. U Saveznoj Republici Njemačkoj, međutim Savezni je financijski sud (njem. Bundesfinanzhof) uspostavio primat koncepcije privatnog prava u tumačenju poreznih zakona, a iz novog Zakona o javnim davanjima (njem. Abgabenordnung) donesenog 1977. godine, ${ }^{14}$ izostavljena je klauzula o ,gospodarskoj interpretaciji“, ali je ugrađeno nekoliko novih odredaba. ${ }^{15}$ Tako novi Zakon o javnim davanjima ${ }^{16}$ čl. 40. propisuje da će se oporezivati svaka transakcija, makar bila i protuzakonita (na primjer oporezuje se i dobit ostvarena prodajom narkotika, nedozvoljeno priređivanje igara na sreću, prostitucija i slično), odnosno za oporezivanje bi trebalo biti sporedno ako je potpuno ili djelomično oporeziva djelatnost suprotna zakonu, zabrani ili javnom poretku. ${ }^{17}{ }^{18}$ Istina, njemački Savezni ustavni sud (njem. Bundesverfassungsgericht), oprezno zauzima stajalište da „sudskim odlukama u poreznom pravu nije zabranjeno da pridaju značaj izmijenjenim gospodarskim okolnostima putem razvijanja prava (njem. Rechtsfortbildung)“.

U austrijskom poreznom pravu načelo gospodarskog pristupa činjenicama bitnima za oporezivanje propisano je u čl. 21. Saveznog zakona o javnim davanjima (njem. Bundesabgabenordnung - BAO). Ta odredba navodi: „sukladno načelu gospodarskog pristupa nužno je uzeti u obzir pravu ekonomsku bit pravnoga posla (njem. wahre wirtschaftliche Gehalt) pri odlučivanju o poreznim pitanjima (njem. die eurteilung abgabenrechtlicher Fragen), a ne izvanjski privid činjenica (njem. nicht die äußere Erscheinungsform des Sachverhaltes maßgebend)“.19

Tako, primjerice, u Sjedinjenim Američkim Državama američki sudovi oslanjali su se na interpretativna načela koja su se temeljila na ekonomskoj stvarnosti transakcija poreznih obveznika. Proliferacijom prijevarnih ponašanja od strane poreznih obveznika i agresivnog poreznog planiranja, u Sjedinjenim Američkim

14 BGB1. I S. 613, ber, 1977. I S. 269., 1. Januar 1977.

15 D. Popović, Poresko pravo, Pravni fakultet Beograd, Beograd, 2008., str. 47.

16 Art. 6. G vom 18. Juli 2017., (BGB1. I S. 2745, 2751), 29. Juli 2017., (Art. 12. G vom 18. Juli 2017.).

17 Abgabenordnung, 9. Auflage, Hemmer Wüst Verlag, Würzburg, 2016., str. 19-20.

18 Zanimljivo je navesti da je Zakonom o prostituciji (njem. Prostituiertenschutzgesetz) prostitucija legalizirana kao i svaka druga djelatnost koja se obavlja na tržištu. Stoga se prostitucija oporezuje prema Zakonu o porezu na dohodak (njem. Einkommensteuergesetz) kao dohodak od samostalne djelatnosti - slobodna zanimanja. Iako je ta djelatnost protivna čl. 138. I njemačkog građanskog zakonika (njem. Bürgerliches Gesetzbuch - BGB), odnosno takve se djelatnosti s aspekta građanskog prava smatraju ništetnim, dok s poreznog aspekta proizvode pravne učinke i oporezuju se. Navedeno prema: Schmidt, Einkommensteuergesetz: EStG, 36. völlig neubearbeitete Auflage, C. H. Beck, München, 2017., str. 25.

19 BGBl. Nr. 194/1961, 28. Juni 1961., BGBl. I Nr. 136/2017. Također podrobnije vidjeti u: D. Hohenwarter, „Austria Report“ u: G. Maisto, Tax treaties and Domestic Law, IBFD, 2006., str. 194. 
Državama su se u posljednjih dvadeset godina razvile mnogobrojne teorije poput substance over form doctrine, step transaction, sham transaction ili economic substance (XE economic substance). Često su ih sudovi upotrebljavali zajedno, kako bi spriječili stjecanje koristi iz prijevarnih ponašanja. ${ }^{20}$

Sve te doktrine, osim economic substance, nisu imale pravnu podlogu. Sukladno toj teoriji, činjenice se trebaju utvrditi prema njihovoj ekonomskoj realnosti, a ne prema njihovoj formi. Vrlo slično nalaže i doktrina step transaction u smislu da ovlašćuje američku poreznu upravu (Internal Revenue Service - IRS) da otkloni pravnu formu kako bi došla do prave ekonomske supstancije određenog pravnog posla. U slučaju doktrine step transaction, više zasebnih pravnih poslova može se promatrati kao jedan jedinstveni pravni posao za potrebe oporezivanja. Napokon, doktrina economic substance, koja je inicijalno nastala u presudi Gregory v. Helvering (1935. godine), da bi potom bila regulirana u ožujku 2010. godine u američkom poreznom zakoniku „Internal Revenu Code“ (IRC), služila je kao metoda za utvrđivanje činjenica koja je dopuštala poreznoj upravi da ne prizna određene porezne povlastice i prednosti u slučajevima u kojima je pravni posao bio poduzet isključivo u svrhu smanjenja porezne obveze (US: SC, 2008, Boulware v. United States, 552 U.S. 421 (2008)). Međutim, promotrimo li pozornije tu doktrinu na način na koji je ista normirana u čl. 7701(o) IRC-a, odnosno u slučaju postojanja neke transakcije u kojoj je postojanje ekonomske biti relevantno, takva će se transakcija smatrati da ima ekonomsku bit, samo ako: a) transakcija smisleno mijenja ekonomsku situaciju poreznog obveznika (osim poreznih posljedica) i ako b) porezni obveznik ima neku stvarnu potrebu za ulazak u tu transakciju (osim postizanja poreznih učinaka). ${ }^{21}$

\section{PRIVIDNI I PRIKRIVENI PRAVNI POSLOVI U GRAĐANSKO-PRAVNOM SMISLU}

U skladu s gore navedenim, a neposredno vezano za gospodarski pristup činjenicama bitnima za oporezivanje, na istom je tragu moguće istaknuti prividne i prikrivene pravne poslove.

Riječ fiktivan odnosno fikcija dolazi od lat. fictus, fingere $=$ izmišljen, promišljen, lažan, nepostojeći, prividan. U pravnoj praksi, fikcija je (engl. fiction of law, njem. (Fiktion), franc. (fiction) pravna činjenica za koju se zna da se nije dogodila ili da se neće dogoditi, ali se uzima kao da se dogodila, kako bi mogao nastati, promijeniti se ili prestati pravni odnos (stav, zaključak, ili misao o toj činjenici). ${ }^{22}$

20 N. Čičin Šain, „Postoji li potreba za općim pravilom za sprečavanje izbjegavanja poreza u hrvatskom poreznom pravu, tzv. Gaar?", Pravni vjesnik, br. 2., Pravni fakultet Sveučilišta u Osijeku, Osijek, 2016., str. 113.

21 Ibid., str. 113-114.

22 Z. Vukšić, „Otkrivanje fiktivnih poslova pri poreznom nadzoru“, Porezni vjesnik, br. 12., Institut za javne financije, Zagreb, 2010., str. 32. 
Pravni posao zaključuje se ugovorom (lat. contractus, engl. contract, njem. Vertrag, franc. contrat). Ugovorom se, prema tome, može smatrati dokument o zaključenju pravnog posla suglasnim očitovanjem volja dviju ili više osoba (pravnih, fizičkih, građana) što bi imao proizvesti dopuštene pravne učinke - postanak, prestanak ili promjenu pravnog odnosa. ${ }^{23}$

Prividan je (simuliran ili fiktivan) ugovor kakav nije sklopljen suglasnošću volje ugovornih strana, nego suglasnošću volje ugovornih strana da se stvori samo privid (fikcija) o zaključenju ugovora.

Prividan (simuliran ili fiktivan) pravni posao porezni obveznici zaista zaključuju, ali su pri tom suglasni da ga uopće ne žele zaključiti, ili žele, ali pravni posao s drugačijim sadržajem i pravnim učincima u usporedbi s onim što ga u potpisanu dokumentu prikazuju prema vani. Simulacija je oblik svjesna nesklada volje i očitovanja, tj. izjavljena volja ne odgovara unutarnjoj volji poreznog obveznika koji zaista ne žele zaključenje pravnog posla i nastup pravnih učinaka toga posla, pa njihova očitovanja volje zato ne mogu dovesti do nastanka posla. ${ }^{24} 25$

Prividni ugovori opisani su u čl. 285. st. 1. Zakona o obveznim odnosima ${ }^{26}$ gdje se propisuje da prividan ugovor nema učinka među ugovornim stranama.

Iz navedene zakonske odredbe zaključuje se da se radi o tzv. „,apsolutnoj simulaciji“, odnosno kada je sklopljen ugovor među strankama koje takav ugovor uopće nisu željele sklopiti. Takav je ugovor zapravo ništetan, jer ne postoji volja stranaka.

Drugim riječima, to su poslovi u kojima stranke prema trećima namjerno i sporazumno simuliraju zaključenje pravnog posla, a među njima zapravo ne nastaje nikakav pravni odnos jer niti žele zaključiti pravni posao niti njegove moguće učinke. ${ }^{27}$

U čl. 285. st. 2. Zakona o obveznim odnosima propisuje se ako prividan ugovor prikriva neki drugi ugovor, taj drugi vrijedi ako je udovoljeno pretpostavkama za njegovu pravnu valjanost.

23 Ibid.

24 Ibid., str. 33.

25 Najčešći je cilj zaključivanja prividnih pravnih poslova zaobići pravne propise, izigrati nekoga trećeg, prikriti od trećih stvarne nakane, steći materijalnu dobit i slično.

26 Narodne novine, br. 35/05, 41/08, 125/11 i 78/15.

${ }_{27}$ Kod prividnog (simuliranog) ugovora postoji svjestan nesklad između volje i očitovanja (mana volje), a nastaje kad se ugovorne strane sporazumno i namjerno očituju o sklapanju određenog ugovora da bi se kod trećih osoba izazvao lažan dojam, iako one ne žele da ugovor nastane i pravno djeluje. Između ugovornih strana prividan ugovor nema pravnog učinka, ništetan je i s njim se postupa kao da nije niti sklopljen. Ništetnost tog pravnog posla djeluje ex tunc, tj. od samog trenutka njegova sklapanja i zato se on ne može pobijati (Sudska odluka Županijskog suda Republike Hrvatske u Varaždinu, broj: Gž 851/08-2., od 2. lipnja 2008. godine). Bitna pretpostavka za postojanje prividnog ugovora jest suglasnost volja ugovornih stranaka o njegovoj prividnosti, odnosno suglasnost o sklapanju nekog drugog (,,pravog“") ugovora koji taj prividni ugovor prikriva. Mora postojati svijest - ugovorna volja o stvarnom sklapanju oba ugovora, a pobude iz kojih su ugovori sklopljeni ne utječu na njihovu valjanost (Sudska odluka Ustavnog suda Republike Hrvatske, broj: U-III/2752/2013., od 15. listopada 2015. godine). 
Dr. sc. Zoran Šinković: Načelo gospodarskog pristupa činjenicama bitnima za oporezivanje Zbornik radova Pravnog fakulteta u Splitu, god. 55, 1/2018., str. 201.- 219.

Iz navedene zakonske odredbe zaključuje se da se radi o tzv. „relativnoj simulaciji“", odnosno situaciji u kojoj su stranke sklopile ugovor kako bi prikrile neki drugi ugovor koji su zapravo željele sklopiti. I u ovoj situaciji postoji ništetnost ugovora zbog pomanjkanja volje stranaka, no kako su stranke ipak htjele sklopiti drugi ugovor, taj drugi ugovor bit će važeći.

Drugim riječima, posrijedi je tzv. „relativna simulacija“ namjerna i radi se o sporazumnom zaključenju pravnog posla koji stranke ne žele, kako bi se prikrio drugi pravni posao kakav udovoljava stvarnoj volji (prikriveni ili disimuliran pravni posao), isti je valjan i proizvodi pravne učinke među strankama. ${ }^{28}$

U čl. 285. st. 3. Zakona o obveznim odnosima propisano je da se prividnost ugovora ne može isticati prema trećoj savjesnoj osobi. Treći je savjestan, ako nije znao niti morao znati da je pravni posao prividan (simuliran ili fiktivan). ${ }^{29}$

\section{PRIVIDNI I PRIKRIVENI PRAVNI POSLOVI U POREZNO- PRAVNOM SMISLU - ZLOUPORABA PRAVA}

U francuskom pravu, koncept zlouporabe prava prenesen je iz drugih grana prava u porezno pravo pa je stoga potrebno referirati se na te grane prava. Ta bi se transpozicija mogla opisati kao prenošenje jedne teorije, nastale u jurisprudenciji sudova, koja je bila naknadno legitimizirana zasebnim pravnim temeljem. ${ }^{30}$

28 Tek kad bi se utvrdilo postojanje svih bitnih sastojaka nekog drugog, određenog pravnog posla (disimuliranog ugovora), moglo bi se prosuđivati pitanje njegove valjanosti i postojanje obveze među strankama ugovora (Sudska odluka Zupanijskog suda Republike Hrvatske u Dubrovniku, broj: Gž 1073/15., od 28. studenog 2016. godine). Pod tom pretpostavkom, a i s obzirom na to da ga stranke doista žele, disimulirani pravni posao je valjan i proizvodi pravne učinke među ugovornim strankama pa takav pravni posao nije ništetan te nema osnove za prihvaćanje tužbenog zahtjeva za utvrđenje disimuliranog pravnog posla ništetnim (Sudska odluka Županijskog suda Republike Hrvatske u Splitu, broj: Gžp 929/2009-1., od 10. ožujka 2011. godine). No, primjerice, disimuliranog ugovora nema ako su prednici tužitelja, istina, htjeli jedan drugi ugovor - ugovor o doživotnom uzdržavanju, ali ne s tuženikom s kojim je potpisan ugovor već s njegovim ocem (imaju isto ime i prezime) s kojim su i pregovarali. On pak takav ugovor nije zaključio time da bi ga prikrio ugovorom o prodaji (Sudska odluka Vrhovnog suda Republike Hrvatske, broj: Rev 2235/1990-2., od 22. prosinca 1992. godine).

29 Prividnost ugovora ne može se isticati prema trećoj, savjesnoj osobi. Ako je jedna ugovorna stranka, znajući da je ugovor prividan, isplatila temeljem tog ugovora određen novčani iznos trećoj osobi i time tu treću osobu održavala u zabludi da se pridržava prividnog ugovora, ne može zahtijevati vraćanje isplaćenog novčanog iznosa od te treće savjesne osobe, a niti isplaćeni novčani iznos potraživati od druge ugovorne stranke prema odredbama o naknadi štete (Sudska odluka Visokog trgovačkog suda Republike Hrvatske, broj: Pž-6070/08., od 17. prosinca 2008. godine). U slučaju kada je treća osoba bila savjesna, a zbog fiktivnog ugovora je nešto dala, onda joj se to što je dala mora vratiti, a pored toga ima pravo tražiti naknadu štete od ugovornih stranaka. Kada je treća osoba bila nesavjesna, jer je znala ili morala znati da je predmetni ugovor fiktivan, vraća joj se ono što je dala ili primila, ali nema pravo na naknadu štete od ugovornih stranaka (Sudska Odluka Visokog trgovačkog suda Republike Hrvatske, broj: Pž 5276/07-3., od 20. studenog 2007. godine).

30 N. Čičin Šain, Postoji... o. c., str. 107., C. Robbez Masson, La notion d'évasion fiscale en droit interne français, LGDJ, 1990., str. 195. 
Zlouporaba prava (u širem smislu) može se provesti na dva načina - prvo preko prividnog (simuliranog fiktivnog) pravnog posla, a drugo preko zlouporabe prava u užem smislu - izbjegavanje poreza.

U prvom je slučaju riječ o aktu/ponašanju poreznog obveznika (no nestvarnom) iz kojeg se pokaže stanoviti izmišljeni posao ili se prikriva stvarna priroda ostvarenog pravnog posla. U drugom pak slučaju porezni obveznik traži olakšice slijedom doslovne primjene teksta ili odluke no u suprotnom smjeru od zamišljenih ciljeva, pri čemu je njegovo ponašanje motivirano isključivo izbjegavanjem ili umanjivanjem poreznih obveza koje bi inače morao podnijeti s obzirom na svoju situaciju ili stvarne aktivnosti. ${ }^{31}$

Zanimljivo je da francuska porezno-pravna teorija, točnije njihov eminentni profesor poreznog prava Maurice Cozian, razlikuje simulaciju kao posljedicu fiktivnih ugovora (franc. actes fictifs), ,zamaskiranih ugovora“ (franc. actes déguisés) te onih gdje postoji interpozicija određene osobe (franc. interposition de personnes). Prva vrsta simulacije postoji kada simulirani pravni posao zapravo uopće ne postoji u stvarnosti, a druga vrsta postoji kada isti postoji u stvarnosti, ali su stranke zapravo njime htjele postići neku drugu svrhu (slično njemačkoj teoriji odnosno primjeru iz sudske prakse, tzv. „unakrsne najamnine“). ${ }^{32}$ Treća vrsta simulacije naziva se simulacija preko interpozicije određene osobe, gdje je zapravo riječ o tome da je pravni posao realan, no da je stranka tog pravnog posla fingirana (ovdje se koristi termin pravni posao koji je širi od pojma ugovor jer obuhvaća i jednostrane pravne poslove). Prava stranka tog posla ostaje sakrivena, sve dok „osoba koja je posudila ime“" (franc. le prête-nom, odnosno l'homme de paille slobodni je prijevod „čovjek od slame“) nastupa otvoreno kao stranka pravnog posla. ${ }^{33}$ Primjenom članka L 132115 Code civila, francuskog građanskog zakonika, porezna uprava, koja se smatra trećom stranom, ima izbor između toga da prihvati pravni posao koji je simuliran i da oporezuje vidljivu stranku ili da ga ne prihvati te da oporezuje stranku disimuliranog pravnog posla. ${ }^{34}$

U čl. 12. st. 1. hrvatskog Općeg poreznog zakona propisano je ako se prividnim pravnim poslom prikriva neki drugi pravni posao, tada je osnova za utvrđivanje porezne obveze prikriveni pravni posao. Analizirajući navedenu zakonsku odredbu, dade se zaključiti da se ovdje radi o „načelu sprečavanja zlouporabe pravne norme“.

„Budući da visina, pa čak i postojanje, porezne obveze mogu ovisiti o pravnoj formi nekog posla, porezni obveznik može, radi nezakonitog izbjegavanja porezne obveze, pravni posao koji doista ima namjeru sklopiti, prikriti drugim pravnim poslom, s drugačijim, za njega povoljnijim, poreznim posljedicama. Taj se drugi pravni posao (koji prikriva stvarne namjere poreznog obveznika) naziva prividnim pravnim poslom (... $)^{“ 3} .{ }^{35}$ Primjenom ovog načela, porezna tijela imaju

31 T. Rogić Lugarić i drugi, Pravni status... o. c., str. 186.

32 O tzv. ,unakrsnoj najamnini“ bit će više riječi poslije.

33 N. Čičin Šain, Postoji... o. c., str. 109.

34 Ibid.

35 J. Šimović i drugi, Hrvatski fiskalni sustav, Narodne novine, Zagreb, 2010., str. 232. 
pravo „dekvalifikacije“ pravnog posla, odnosno njegove karakterizacije sukladne odredbama ugovora ali zanemarujući prividni posao koji vodi izbjegavanju porezne obveze ili, drugačije rečeno, „smatrajući ga sklopljenim u pravnoj formi koja je odraz stvarne namjere osobe koja je zainteresirana sklopiti takav pravni posao". 3637

Ne treba zanemariti ni činjenicu da je mašta ljudi u lažiranju financijskih izvješća, ${ }^{38}$ poreznih prijava, sklapanja prividnih ugovora i slično neograničena, ali ipak postoji iskustvo, spoznaje o tome kako ih se najčešće lažira. ${ }^{39} \mathrm{Za}$ otkrivanje prividnih pravnih poslova nužna su interdisciplinarna znanja u području poreznog prava, upravnog prava, građanskog prava, trgovačkog prava, prava društava, računovodstva, financija i slično.

Prividnost određenog pravnog posla može proisteći iz fiktivnosti samog poreznog obveznika ili iz fiktivnosti poslovne dokumentacije. Osim fiktivne dokumentacije, postoje, naravno, fiktivni obveznici, u kakvih najčešće nema zaposlenih, nema poslovnih prostorija, nedavno su osnovani ili je promijenjen vlasnik, različito je prebivalište vlasnika i sjedište obveznika, sjedište je na nepostojećoj ili adresi privatnog stana, nema poslovne imovine kakvu bi se možda moglo zaplijeniti, nije upisan u sudski registar ili je upisan fiktivan identitet ili nepostojeća osoba... ${ }^{40}$

Fiktivna dokumentacija jest dokumentacija koja se sastoji od fiktivnih poslovnih dokumenata, ugovora ili temeljnica (poslovne knjige, računi...). ${ }^{41}$

Zanimljivo se osvrnuti na praksu porezne uprave i praksu upravnih sudova u Republici Hrvatskoj vezanu za prividne pravne poslove.

Postoje sadržajno različiti prividni pravni poslovi, otkriveni u poreznom nadzoru: 1) porezni obveznici sklopili su ugovor o darovanju (prividni pravni posao), kako bi prikrili kupoprodajni ugovor koji stvarno žele (prikriveni pravni posao), 2) u poslovnim knjigama prikazan fiktivan izvoz robe za poznate kupce, 3 ) izdavanje fiktivnih računa na nepostojeće kupce u inozemstvu s umanjenim porezom na dodanu vrijednost, 4) pribavljanje fiktivnih ulaznih računa od nepostojećih dobavljača radi povećanja ulaznoga poreza na dodanu vrijednost te umanjenja mjesečne ili konačne obveze poreza na dodanu vrijednost ili povrata poreza na dodanu vrijednost, 5)

36 Ibid., str. 233.

37 Ovdje je riječ o doktrini simulacije koja se upotrebljava u nizu zemalja kontinentalno-pravne tradicije (izvorno je riječ o institutu podrijetlom iz građanskog prava) i koja se smatra svojevrsnim ekvivalentom konceptu ,prijetvornih, simuliranih transakcija“ u zemljama tradicije precedentnog prava, a počiva na „pravnoj stvarnosti“. Navedeno prema: T. Rogić Lugarić i drugi, Pravni status... o. c., str. 195.

38 Također se u praksi primjenjuje Beneisheov model utvrđivanja mogućeg stupnja manipulacija u financijskim izvješćima. Podrobnije vidjeti u: Z. Vukšić, Benfordov zakon u poreznom nadzoru, Informator br. 5700., od 22. listopada 2008., Novi informator d. o. o., Zagreb, 2008., str. 11-18., Z. Vukšić i drugi, „Upravljanje rizicima u planiranju poreznog nadzora“, poseban broj Poreznog vjesnika, listopad 2009., Institut za javne financije, Zagreb, 2009., str. 82-92, V. Belak, Forenzično računovodstvo, RRIF Konzalting, Zagreb, 2009., str. 156-162.

39 Usporediti Z. Vukšić, „Provedbe poreznog nadzora - Porezne i računovodstvene prijevare poreza na dobit“, poseban broj Poreznog vjesnika, lipanj 2010., Institut za javne financije, Zagreb, 2010., str. 336361 .

40 Z. Vukšić, Otkrivanje... o. c., str. 35.

41 Ibid. 
fiktivno prikazivanje manje vrijednosti robe (osobito pri uvozu) radi umanjenja osnovice za obračun poreza na dodanu vrijednost, 6) fiktivno prikazivanje umanjenoga ili uvećanog prometa, 7) fiktivno planiranje nesolventnosti tako što svjesno izazvanom nesolventnošću obveznik dolazi u situaciju da ne može namiriti obvezu poreza na dodanu vrijednost koji je njegov kupac već odbio (uračunao) kao ulazni porez na dodanu vrijednost, 8) fiktivni obveznik koji ne obavlja bilo kakav promet, ali predaje prijave poreza na dodanu vrijednost u kojima iskazuje pretplatu u velikoj svoti, nakon čega zahtijeva povrat ili prikazuje malene pretplate i sukcesivno neprimjetno ostvaruje povrate, 9) uključivanje fiktivnog obveznika u lanac prometa dvaju stvarnih obveznika od kojih je jedan kupac a drugi dobavljač, tako da im fiktivni obveznik služi kao „tampon“ za umanjivanje poreza na dodanu vrijednost i slično. ${ }^{42}$

Upravni sudovi Republike Hrvatske donijeli su niz presuda u kojima su sudili o prividnim pravnim poslovima. Navest ćemo neke od njih: 1) ugovor o kupoprodaji zapravo simulira ugovor o kreditu (zajmu) - porez na dodanu vrijednost ne može se odbiti jer je riječ o prividnom ugovoru, ${ }^{43} 2$ ) porezna uprava je ovlaštena utvrditi da je neki prikriveni pravni akt taj koji će poslužiti za utvrđivanje porezne osnovice - ugovorom o zajmu zapravo se prikriva plaćanje, ${ }^{44} 3$ ) prividnim pravnim poslom to jest prodajom poslovnih udjela jednog trgovačkog društva drugom trgovačkom društvu htjelo se prikriti drugi pravni posao odnosno kupoprodaju nekretnina, ${ }^{45} 4$ ) pravilno je porezno tijelo utvrdilo da se radi o zamjeni nekretnina te da su ugovori o darovanju sklopljeni isključivo u svrhu prikrivanja stjecanja nekretnina na temelju naplatnog pravnog posla koji bi bio predmet oporezivanja, ${ }^{46} 5$ ) pravilno je porezno tijelo utvrdilo kako je fakturiranje najma broda prividni pravni posao kojim se nastoji prikriti izuzimanje broda - plovila iz imovine društva i njegovo korištenje u privatne svrhe. ${ }^{47}$

S obzirom na to da hrvatsko porezno pravo već posjeduje mjeru za suzbijanje zlouporabe prava uz pomoć simulacije (prividni pravni poslovi), ne postoji potreba za uvođenjem nekog novog pravila o izbjegavanju plaćanja poreza koji bi imao u sebi tu komponentu. ${ }^{48}$

42 Ibid., str. 45. godine.

43 Sudska odluka Upravnog suda Republike Hrvatske, broj: Us-10297/2004., od 4. lipnja 2008.

44 Sudska odluka Upravnog suda Republike Hrvatske, broj: Us-6583/2005., od 2. srpnja 2008. godine.

45 Sudska odluka Upravnog suda Republike Hrvatske u Rijeci, broj: 1 Usl-226/12-20., od 21. rujna 2012. godine.

46 Sudska odluka Upravnog suda Republike Hrvatske u Rijeci, broj: 5 UsI-1147/12-12., od 17. siječnja 2014. godine.

47 Sudska odluka Visokog Upravnog suda Republike Hrvatske, broj: Us-11117/2011-7., od 13. studenoga 2014. godine.

48 U svezi s prividnim pravnim poslovima, opće materijalno-pravno značenje ima i odredba čl. 31. Općeg poreznog zakona u kojoj se taksativno navode posebni slučajevi odgovornosti, u kojima će se u svakom slučaju uspostaviti odgovornost obje skupine osoba kao zakonskih poreznih jamaca. Zapravo se radi o preuzimanju odredbi Kaznenog zakona i Zakona o trgovačkim društvima koje se odnose na 


\section{PRIVIDNI I PRIKRIVENI PRAVNI POSLOVI U POREZNO- PRAVNOM SMISLU U KOMPARATIVNIM POREZNIM SUSTAVIMA}

U Saveznoj Republici Njemačkoj, u čl. 41. Zakona o javnim davanjima, propisano je, kao što je već rečeno, da će se oporezivati i oni pravni poslovi koji su ništetni $\mathrm{s}$ aspekta privatnog, odnosno poslovnog prava, ukoliko se realizirala gospodarska suština transakcije i posebno nalaže da se kod prividnog pravnog posla oporezivanju ima podvrći prikriveni pravni posao. U čl. 42 . Zakona o javnim davanjima propisano je da se porez ne može izbjeći zlouporabom pravnih formi (konstrukcija). Kada se ustanovi zlouporaba pravne forme (konstrukcije), porezni zahtjev će se zasnivati na pravnoj formi transakcije koja je odgovarajuća faktičnoj situaciji. Smatra se da postoji zlouporaba kada pravna forma upotrijebljena od strane poreznog obveznika nije odgovarajuća faktičnoj gospodarskoj situaciji. Ključna riječ u ovoj odredbi jest „odgovarajuća“, ona podrazumijeva da faktične posljedice neke transakcije budu manje-više konzistentne s pravnom formom te transakcije. Zlouporaba se sastoji u izboru pravne forme koja je neodgovarajuća tom gospodarskom odnosu da bi se izbjegao porez. ${ }^{49}$

Zanimljivo je navesti i jedan primjer iz sudske prakse Savezne Republike Njemačke: S i T su susjedi. Stanuju u istoj zgradi (isti kat, stan do stana i svaki stan ima isti broj metara kvadratnih). S i T sklapaju dva ugovora o najmu (stana) na način da S iznajmljuje svoj stan T-u, a T svoj stan iznajmljuje S-u. Obojica plaćaju, na temelju sklopljenog ugovora, najamninu jedan drugome (isti su novčani iznosi najamnine) i porez na dohodak od imovine i imovinskih prava u skladu s odredbama Zakona o porezu na dohodak. S i T traže poreznu olakšicu u svezi s plaćanjem poreza na dohodak od imovine i imovinskih prava. Sud smatra da su oba ugovora o najamnini fiktivni odnosno prividni pravni poslovi, odnosno da ne postoji svrhovitost gospodarske transakcije koja se želi postići sklapanjem takvih ugovora, već se radi o zlouporabi pravne forme (transakcije) kako bi se mogla ostvariti porezna olakšica, stoga sud ne priznaje pravo na poreznu olakšicu. Sud navodi da

određena gospodarska kaznena djela. Očito je namjera zakonodavca da odgovornost poreznog jamca protegne na osobe koje su izvršile radnju (činjenje ili nečinjenje), koja je dio bića taksativno navedenih, gospodarskih kaznenih djela. Pretpostavlja se, naime, da takve radnje mogu osobito utjecati na nemogućnost naplate poreznog duga. Te su radnje: 1. prividni ili besplatni prijenos imovine trgovačkog društva (glavnog poreznog dužnika) na trgovačko društvo, koje su osnovali sami ili s drugim osobama, drugi oblici prividne prodaje, opterećenja bez odgovarajuće protučinidbe ili besplatnog ustupa povezanim osobama, cijele ili dijela imovine, slučajevi oštećenja, uništenja ili činjenja neupotrebljivom imovine trgovačkog društva, 2. zaključenje prividnog pravnog posla ili priznanje nepostojeće tražbine trgovačkom društvu koje su osnovali sami ili s drugim osobama, 3. umanjenje imovine ili prikrivanje imovinskog stanja, nepodnošenje zakonom propisanih godišnjih izvješća, nepokretanje stečajnog postupka. Navedeno prema: N. Žunić Kovačević i drugi, „Institut zakonskog poreznog jamstva nakon novele Općeg poreznog zakona 2012.: 'Proboj pravne osobnosti' trgovačkih društava u slučaju zloporabe prava“, Zbornik radova Pravnog fakulteta Sveučilišta u Rijeci, vol. 34., br. 1., Pravni fakultet Sveučilišta u Rijeci, Rijeka, 2013. str. 400. Također vidjeti: Sudska odluka Ustavnog suda Republike Hrvatske, broj: U-III-6657/2014., od 19. listopada 2016. godine, Sudska odluka Ustavnog suda Republike Hrvatske, broj: U-III-1882/2015., od 21. travnja 2016. godine.

49 Abgabenordnung... o. c., str. 20. 
su takvi ugovori gospodarski besmisleni i naziva ih tzv. "unakrsnim najamninama“ (njem. „Überkreuzvermietung“). ${ }^{50}$

$\mathrm{U}$ austrijskom poreznom pravu odnosno u Saveznom zakonu o javnim davanjima nalazi se mjera u glavi zakona koja nosi naziv (njem. „Wirtschaftliche Betrachtungsweise“). Međutim, ta glava sadrži i opću odredbu za sprečavanje izbjegavanja plaćanja poreza, koja se nalazi u čl. 22. navedenog zakona. Ta odredba propisuje kako se porezne obveze ne mogu izbjeći zlouporabom pravnih oblika ili metoda koje predviđa građansko pravo. Postoji li zlouporaba prava, porez koji se treba naplatiti bit će onaj koji bi se trebao platiti da je porezni obveznik odabrao neku pravnu formu koja je primjerena ekonomskim odnosima, činjenicama i okolnostima (njem. den wirtschaftlichen Vorgängen, Tatsachen und Verhältnissen angemessenen rechtlichen Gestaltung zu erheben wären). ${ }^{51}$

Fitzwilliam v IRC (1993.) 3 All E. R. 184 (HL) jest slučaj iz Ujedinjenog Kraljevstva, u kojemu je riječ o shemi za izbjegavanje poreza na nasljedstvo. Grof Fitzwilliam umro je 1979. godine, ostavivši vrijedno imanje dvogodišnjem diskrecijskom trustu čiji su članovi imali pravo dodijeliti imovinu kategoriji korisnika koja je obuhvatila grofovu udovicu groficu Fitzwilliam i njegovu pokćerku groficu Hastings. Prema važećem propisu, ono što je dodjeljivano iz trusta bilo bi oporezivano kao da je učinjeno po grofovoj volji. Problem s kojim su se susreli članovi trusta bilo je zakonito izbjegavanje poreza na prijenos imovine. Imovina prenesena grofici Hastings bila bi podložna oporezivanju po stopi od gotovo 75 $\%$. Relevantni propisi predviđali su oslobađanje za prijenos među supružnicima, tako da je imovina mogla biti dodijeljena grofici Fitzwilliam bez većih problema. Međutim, za nju se nije očekivalo da će još dugo poživjeti, tako da bi nakon njezine smrti iskrsnuo isti problem. Da bi izbjegli oporezivanje nasljedstva, članovi trusta i njihovi porezni savjetnici razvili su shemu koja se sastojala od pet faza. Prema njezinu potpunom ostvarenju, otprilike dvije trećine imovine bile su dodijeljene groficama Fitzwilliam i Hastings, a činilo se da nijedna nije obveznica poreza na nasljedstva. Ekonomske su situacije poreznih obveznica bile gotovo istovjetne prije i nakon ostvarenja sheme. Ujedinjeno Kraljevstvo nema općeg pravila. Ono se, umjesto toga, oslanja na sudski stvorenu doktrinu, uobičajeno poznatu kao doktrina Ramsey, radi suzbijanja zakonitog izbjegavanja poreza. Prema toj doktrini, shema je u osnovi samoukidajuća, ako je porezni obveznik u istom položaju prije i nakon primjene sheme; osim po poreznoj pogodnosti koju je ciljano ostvario, shema može biti zanemarena u smislu oporezivanja ( $\mathrm{tj}$. sama shema sadržava razloge za svoje ukidanje).$^{52}$ Doktrina je razvijena putem kasnijih rješidbi, ali u vrijeme slučaja Fitzwilliam porezne su vlasti morale dokazati koji se dijelovi sheme mogu ocijeniti samoukidajućima i koji je primjereni iznos poreza što treba biti plaćen. Porezne su

50 Ibid.

51 M. Kotschnigg, Beweisrecht der BAO, Spezialkommentar, Facultas WUV, Wien, 2011., R. Christoph, Bundesabgabenordnung - Kommentar, 5. Auflage, Linde Verlag, Wien, 2013.

52 W. T. Ramsey v IRC (1981.), 53 TC 101, 185 Lord Wilberforce u: M. Gammie, „Tax Avoidance and the Rule of Law: A Perspective from the United Kingdom“ in: S. Graeme Cooper, ed., Tax Avoidance and the Rule of Law, IBFD, Amsterdam, 1997., str. 189-190. 
vlasti smatrale taj zadatak razmjerno teškim, osobito stoga što nisu mogle odlučiti čini li svih pet koraka konstrukcije shemu ili neki od njih imaju neovisne ekonomske učinke. O slučaju je konačno odlučeno u Domu lordova, koji je donio odluku u korist poreznog obveznika. Bit razloga većine glasača za takvu odluku bila je da shema nije mogla biti ocijenjena kao samoukidajuća jer je, promatrano pojedinačno, određeni broj koraka imao posljedice povezane s porezom na dohodak, što je značilo da sve one ipak nisu mogle biti promatrane naprosto kao dio sveobuhvatne sheme. Slučaj Fitzwilliam ilustrira relativnu neprilagodljivost sudski stvorene doktrine u usporedbi sa zakonskim općim pravilom. Da su se porezne vlasti u slučaju Fitzwilliam mogle pozvati na opće pravilo, vjerojatno bi uspjele ostvariti svoj zahtjev. Jasno je da je shema bila razvijena radi zaobilaženja sustava oporezivanja nasljedstva $\mathrm{i}$ da, zapravo, nije imala drugu svrhu. Zakonom propisano opće pravilo gotovo bi sigurno omogućilo sprečavanje uspjeha sheme, ali sudski zasnovana protuizbjegavajuća doktrina Ujedinjenog Kraljevstva nije bila dorasla zadatku. ${ }^{53}$

Novi španjolski Opći porezni zakon iz 2003. godine uveo je potpuno novo opće pravilo koje jasnije definira izbjegavanje poreza, s ciljem revitalizacije njegove uporabe od strane poreznih tijela i sudova. ${ }^{54}$ Zakonito izbjegavanje poreza, koje se označuje pojmom ,sukob u primjeni poreznih pravila“, obuhvaća dvije skupine slučajeva: 1) slučajevi kod kojih porezni obveznik izbjegava oporezivi događaj ili umanjuje poreznu osnovicu putem transakcije koja je umjetna ili netipična za postizanje ostvarenog rezultata, te 2) transakcije koje dovode do materijalnopravnih ili gospodarskih učinaka ili pogodnosti koje odudaraju od onih koje bi bile ostvarene transakcijama koje nisu umjetne. ${ }^{55}$

Portugalsko opće pravilo propisuje da je svaka transakcija poduzeta na umjetni ili prijevarni način ili zloporabom pravnih formi te s jedinim ili glavnim ciljem ostvarenja poreznih pogodnosti nevažeća za potrebe poreznog prava. Porezna obveza bit će nametnuta u skladu s pravilima koja bi bila primjenjiva u slučaju da transakcija nije poduzeta te se namjeravane ili ostvarene porezne pogodnosti neće priznati. $^{56}$

\section{ZAKLJUČAK}

Porezni zakoni trebaju se tumačiti primjenom svih onih metoda koje se koriste pri tumačenju ostalih zakona. Granice svakog tumačenja određuje princip zakonitosti u svojoj integralnosti. Nedozvoljeno je svako tumačenje koje vodi zlouporabi smisla i funkciji načela zakonitosti. U poreznom pravu polaznu osnovu za tumačenje predstavlja tekst poreznog zakona.

53 R. Prebble, Treba li... o. c., str. 268-269.

54 A. Ruiz, ,Tax Avoidance and the European Court of Justice: What is at Stake for European General Anti-Avoidance Rules?“", Intertax, 33, (12.), 2005., str. 560-582.

55 Podrobnije vidjeti u: S. Gadžo i drugi, Analiza... o . c., str. 286.

56 B. Santiago i drugi, „Updates on Intercorporate Dividends, GAAR, Arbitration“, Journal of International Taxation, Dateline, Portugal, 10. (October), 2011., str. 59-61. 
Budući da svaki pravni pojam i svaki pravni propis često služi ostvarenju većeg broja ciljeva, teleološkom metodom tumačenja moraju se, prije svega, riješiti konflikti u interesima onih koji su tvorci takvog pravnog propisa. Stoga se postavlja pitanje koji je cilj poreznih propisa. Jedan od odgovora mogao bi biti da je cilj poreznih propisa osiguravanje novčanih sredstava državi za ostvarenje njezinih zadataka. Pođe li se kod primjene teleološke metode od tog cilja, tada je osnovni i najhitniji konflikt u poreznim propisima konflikt između poreznog obveznika i države. Dok je interes poreznog obveznika platiti što manje poreza, interes države je, pak, ubirati što više poreznih prihoda. Kod poreznih se propisa, naime, ne radi o interesnom konfliktu između poreznih obveznika i države. Taj konflikt je riješio već sam propis utvrđivanjem visine poreza i određivanjem drugih obveza poreznom obvezniku. Stoga se kod primjene teleološke metode kod poreznih propisa kojima se određuje neka obveza, treba poći od cilja kojim bi se spriječilo da se interesi suprotnih strana ne tumače u ekstremnom smislu, ${ }^{57}$ nego da se porezni propisi ne tumače samo ,in dubio pro fisco“, nego i ,in dubio contra fiscum“.

U tumačenju poreznih propisa gospodarsko tumačenje ima značaju ulogu, stoga predstavlja i specifičnost poreznog prava u odnosu na druge grane prava. Clankom 11. Općeg poreznog zakona propisano je načelo gospodarskog pristupa činjenicama bitnima za oporezivanje odnosno tzv. ,,gospodarski pristup“ u postupku utvrđivanja porezne obveze, kojim se kodificira načelo prevage sadržaja u odnosu na formu. Stoga se oporezivanju imaju podvrgnuti ništetni pravni poslovi (u građanskopravnom smislu) odnosno bitan je sadržaj tog pravnog posla to jest gospodarska supstancija, a nije bitna njegova forma. Međutim, odredbe Općeg poreznog zakona o gospodarskom pristupu nedovoljno su precizne i ne pružaju detaljnije upute za njihovu primjenu poreznim tijelima i sudovima, stoga bi ih u tom smislu trebalo i promijeniti na način da uvijek bude nedvojbeno da cee pravna forma, dakle, biti poništena ako je porezni motiv dominantan ili odlučujući razlog za transakciju sadržanu u nekom pravnom poslu (ugovoru i slično), a da se shodno tome je li porezni motiv takav ne zaključuje na bazi subjektivne namjere poreznog obveznika (koju bi bilo teško utvrditi), nego na osnovi objektivnih činjenica koje ocjenjuju i utvrđuju porezno tijelo i sud. ${ }^{58}$

Neposredno vezano za načelo gospodarskog pristupa činjenicama bitnima za oporezivanje na istom je tragu moguće istaknuti prividne i prikrivene pravne poslove (koje propisuje čl. 12. Općeg poreznog zakona) bez kojih bi primjena navedenog načela u praksi bila znatno otežana. Kao što je već rečeno, načelo gospodarskog pristupa činjenicama bitnima za oporezivanje kodificira načelo prevage sadržaja u odnosu na formu, dok kod prividnih pravnih poslova, kada se ustanovi zlouporaba pravne forme (konstrukcije), porezni zahtjev će se zasnivati na pravnoj formi transakcije koja je odgovarajuća faktičnoj situaciji, a ne izvanjskom prividu činjenica, odnosno faktične posljedice neke transakcije moraju biti manje-

57 Bo. Jelčić i drugi, Financijsko... o. c., str. 539.

58 Usporediti: F. Vanistendeal, „Legal Framework for Taxation“ u: Tax Law Design and Drafting, Vol. I., ed. By Victor Thuronyi, IMF, Washington, D. C., 1996., str. 38-39. 
više konzistentne s pravnom formom te transakcije. Poveznica se sastoji u prevagi sadržaja nad formom, odnosno transakciji koja odgovara faktičnoj situaciji. Stoga bi trebalo promijeniti odredbe Općeg poreznog zakona koje se odnose na prividne pravne poslove i podrobnije navesti što se podrazumijeva pod zlouporabom pravne forme (konstrukcije), na primjer navesti: što se smatra fiktivnom dokumentacijom, tko su fiktivni obveznici, što je fiktivna bilanca, fiktivni kapital, fiktivni dobitak, fiktivni gubitak i slično, jer ne treba zanemariti činjenicu da su za otkrivanje prividnih pravnih poslova (transakcija) nužna interdisciplinarna znanja ne samo u području poreznog prava, nego i upravnog prava, građanskog prava, trgovačkog prava, prava društava, računovodstva, financija i slično, a što bi zasigurno pomoglo da porezna odnosno sudska praksa postanu još kvalitetnije u primjeni poreznih propisa.

\section{POPIS LITERATURE}

Abgabenordnung, 9. Auflage, Hemmer Wüst Verlag, Würzburg, 2016.

C. Atkinson, „General anti-avoidance rules: Exploring the balance between the taxpayer`s need for certainty and the government's need to prevent tax avoidance“, Journal of Australian Taxation, No. 14/12.

V. Belak, Forenzično računovodstvo, RRIF Konzalting, Zagreb, 2009.

D. Birk i drugi, Steuerrecht, 18. Auflage, C. F. Müller, Heidelberg, 2015./16. 2001 .

M. Budić i drugi, Opći porezni zakon s komentarom, Institut za javne financije, Zagreb,

R. Christoph, Bundesabgabenordnung - Kommentar, 5. Auflage, Linde Verlag, Wien, 2013.

N. Čičin Šain, „Postoji li potreba za općim pravilom za sprečavanje izbjegavanja poreza u hrvatskom poreznom pravu, tzv. Gaar?", Pravni vjesnik, br. 2., Pravni fakultet Sveučilišta u Osijeku, Osijek, 2016.

K. D. Drüen, Allgemeines Steuerrecht, 16. Auflage, Alpmann Schmidt, Münster, 2017.

S. Gadžo i drugi, ,Analiza normativnog okvira za sprječavanje zakonitog izbjegavanja poreza u Hrvatskoj: Prijedlog izmjena u skladu s pravom Europske unije“, Financijska teorija i praksa, br. 25., Institut za javne financije, Zagreb, 2014.

D. Hohenwarter, „Austria Report“ u: G. Maisto, Tax treaties and Domestic Law, IBFD, 2006. 2008.

Bo. Jelčić i drugi, Financijsko pravo i financijska znanost, Narodne novine, Zagreb,

M. Kotschnigg, Beweisrecht der BAO, Spezialkommentar, Facultas WUV, Wien, 2011.

D. Popović, Poresko pravo, Pravni fakultet Beograd, Beograd, 2008.

R. Prebble, „Treba li Hrvatska opće pravilo za sprječavanje zakonitog izbjegavanja porezne obveze?, Prijedlog promjena važećega hrvatskog zakonodavstva“, Financijska teorija i praksa, br. 29., Institut za javne financije, Zagreb, 2005. 
W. T. Ramsey v IRC (1981.), 53 TC 101, 185 Lord Wilberforce u: M. Gammie, „Tax Avoidance and the Rule of Law: A Perspective from the United Kingdom“ in: S. Graeme Cooper, ed., Tax Avoidance and the Rule of Law, IBFD, Amsterdam, 1997.

C. Robbez Masson, La notion d'évasion fiscale en droit interne français, LGDJ, 1990.

T. Rogić Lugarić i drugi, „Pravni status poreznih izdataka: Stanje i perspektive“, Zbornik radova „Skrivena javna potrošnja: sadašnjost i budućnost poreznih izdataka“, Institut za javne financije, Zagreb, 2012.

A. Ruiz, „Tax Avoidance and the European Court of Justice: What is at Stake for European General Anti-Avoidance Rules?“, Intertax, 33., (12.), 2005.

B. Santiago i drugi, „Updates on Intercorporate Dividends, GAAR, Arbitration“, Journal of International Taxation, Dateline, Portugal, 10. (October), 2011.

Schmidt, Einkommensteuergesetz: EStG, 36. völlig neubearbeitete Auflage, C. H. Beck, München, 2017.

J. Šimović i drugi, Hrvatski fiskalni sustav, Narodne novine, Zagreb, 2010.

F. Vanistendeal, „Legal Framework for Taxation“ u: Tax Law Design and Drafting, Vol. I., ed. By Victor Thuronyi, IMF, Washington, D. C., 1996.

Z. Vukšić, Benfordov zakon u poreznom nadzoru, Informator br. 5700., od 22. listopada 2008., Novi informator d. o. o., Zagreb, 2008.

Z. Vukšić, „Otkrivanje fiktivnih poslova pri poreznom nadzoru“, Porezni vjesnik, br. 12. Institut za javne financije, Zagreb, 2010.

Z. Vukšić, „Provedbe poreznog nadzora - Porezne i računovodstvene prijevare poreza na dobit“, poseban broj Poreznog vjesnika, lipanj 2010., Institut za javne financije, Zagreb, 2010 .

Z. Vukšić i drugi, „Upravljanje rizicima u planiranju poreznog nadzora“, poseban broj Poreznog vjesnika, listopad 2009., Institut za javne financije, Zagreb, 2009.

N. Žunić Kovačević i drugi, „Institut zakonskog poreznog jamstva nakon novele Općeg poreznog zakona 2012.: 'Proboj pravne osobnosti' trgovačkih društava u slučaju zloporabe prava“, Zbornik radova Pravnog fakulteta Sveučilišta u Rijeci, vol. 34., br. 1., Pravni fakultet Sveučilišta u Rijeci, Rijeka, 2013.

\section{Pravni propisi}

Abgabenordnung, BGB1. I S. 613, ber, 1977. I S. 269., 1. Januar 1977.

Abgabenordnung, Art. 6. G vom 18. Juli 2017., (BGB1. I S. 2745, 2751), 29. Juli 2017. (Art. 12. G vom 18. Juli 2017.).

Bundesabgabenordnung, BGBl. Nr. 194/1961, 28. Juni 1961., BGB1. I Nr. 136/2017.

Opći porezni zakon, Narodne novine, br. 115/16.

Zakon o obveznim odnosima, Narodne novine, br. 35/05, 41/08, 125/11 i 78/15. 


\section{Sudska praksa}

Sudska odluka Upravnog suda Republike Hrvatske, broj: Us-10297/2004., od 4. lipnja 2008. godine.

Sudska odluka Upravnog suda Republike Hrvatske, broj: Us-6583/2005., od 2. srpnja 2008. godine.

Sudska odluka Upravnog suda Republike Hrvatske u Rijeci, broj: 1 Usl-226/12-20., od 21. rujna 2012. godine.

Sudska odluka Upravnog suda Republike Hrvatske u Rijeci, broj: 5 UsI-1147/12-12., od 17. siječnja 2014. godine.

Sudska odluka Ustavnog suda Republike Hrvatske, broj: U-III/2752/2013., od 15. listopada 2015. godine.

Sudska odluka Ustavnog suda Republike Hrvatske, broj: U-III-1882/2015., od 21. travnja 2016. godine.

Sudska odluka Ustavnog suda Republike Hrvatske, broj: U-III-6657/2014., od 19. listopada 2016. godine.

Sudska odluka Visokog Upravnog suda Republike Hrvatske, broj: Us-11117/2011-7., od 13. studenoga 2014. godine.

Sudska Odluka Visokog Trgovačkog suda Republike Hrvatske, broj: Pž 5276/07-3., od 20. studenog 2007. godine.

Sudska odluka Visokog Trgovačkog suda Republike Hrvatske, broj: Pž-6070/08., od 17. prosinca 2008. godine.

Sudska odluka Vrhovnog suda Republike Hrvatske, broj: Rev 2235/1990-2., od 22. prosinca 1992. godine.

Sudska odluka Županijskog suda Republike Hrvatske u Varaždinu, broj: Gž 851/08-2., od 2. lipnja 2008. godine.

Sudska odluka Županijskog suda Republike Hrvatske u Splitu, broj: Gžp 929/2009-1., od 10. ožujka 2011. godine.

Sudska odluka Županijskog suda Republike Hrvatske u Dubrovniku, broj: Gž 1073/15., od 28. studenog 2016. godine. 


\section{ECONOMIC APPROACH TO THE FACTS RELEVANT TO TAXATION}

In interpreting tax regulations, economic interpretation has the importance of the role or principle of economic approach to the facts relevant to taxation, which codifies the principle of overcoming the content in relation to the form. On the same track it is possible to point out sham contracts and legal contracts (transactions) without which the application of this principle in practice was considerably hampered. It is necessary to change the regulataions of the General Tax Act related to the principle of economic approach to the facts relevant to taxation and sham contracts, which would surely help tax or judicial practices become even better in the application of tax regulations.

Key words: economic approach, sham contracts, legal contracts (transactions). 